\title{
Inspiracje Jana Lechonia
}

\author{
Monika Urbańska*
}

Inspiracje Jana Lechonia nie ograniczają się jedynie do literackich. W przypadku tego twórcy mówimy o inspiracji totalnej, obejmującej warsztat pisarski oraz osobowość. Czytając zapiski poety można by uznać, że inspiracje zostały mu narzucone przez matkę, która, jak przyznawał, chciała w nim widzieć drugiego Słowackiego ${ }^{1}$. Słowa te, a właściwie oskarżenia, powtarzał Lechoń kilkakrotnie, akcentując, iż matce wady i słabości wieszcza wydawały się piękne i chciała je widzieć w nim. Pseudonim Leszka Serafinowicza wywodzi się najprawdopodobniej ze sposobu, w jaki zwracała się do niego matka, nazywając go Lecho².

Wpływ rodziców-inteligentów na Lechonia był nie do przecenienia. Kompletowali oni bogatą domową biblioteczkę, kształtowali w synu miłość do literatury i kultury oraz patriotyzm. Byli szlachetnymi i pracowitymi ludźmi. Lechoń podjął wyzwanie postawione mu przez matkę - pierwsze tomiki, Na žłotym polu i Po różych ścię̧kach, ukazały się, gdy miał dwanaście i trzynaście lat. Wiersze w nich pomieszczone, mimo pewnych warsztatowych niedoskonałości, uderzają wiarygodnością stanów emocjonalnych dojrzałego już, jak mogłoby się wydawać, dekadenta. Co znamienne, pierwszy zbiór dedykowany został Leopoldowi Staffowi. Zanim pojawiły się pierwsze tomy, Lechoń, będąc w wieku przedszkolnym, już bawił się w pisarza,

* Uniwersytet Lódzki, Wydział Filologiczny, Instytut Filologii Polskiej i Logopedii, Pracownia Edytorstwa, 90-236 Lódź, ul. Pomorska 171/173, e-mail: monika.urbanska@uni.lodz.pl.

1 J. Lechoń, Dĩiennik, oprac. R. Loth, t. I, Warszawa 1992, s. 80. Zapis z 22 III 1951 r.

2 J. A. Kosiński, Album rodžinne Jana Lechonia, Warszawa 1993, s. 245-246. 
redagując „Gazetę Mamy i Leszka”. Kilka lat później, w „Kurierze Warszawskim" z 1 I 1913 roku, opublikował wiersz Do przyjaciela. W tym samym roku w książce maturzystów zamieścił wiersz Hasło. Dwa lata później napisał obrazek dramatyczny w jednym akcie pt. $W$ noc jesienna, który został wystawiony na przedstawieniu szkolnym. W teatrze w Pomarańczarni wystawiono jego nokturn dramatyczny. Juwenilia Lechonia inspirowane były m.in. poezją Adama Asnyka oraz Młodą Polską. Pojawiają się w nich wyeksploatowane modernistyczne nastroje, melancholia, introspektywna analiza oraz rekwizyty rodem ze starego romantycznego dworku.

Jako siedemnastolatek Lechoń rozpoczął studia, rok później był współredaktorem „Pro Arte et Studio”. Uważano go za wytrawnego mówcę i zatrudniano do przemawiania na wydarzeniach związanych z kulturą. Ponadto działał w kawiarni Pod Picadorem oraz w grupie Skamander.

Cienki tom, zatytułowany Karmazynowy poemat, wydany przez Lechonia w dwudziestym pierwszym roku życia, przyniósł mu nieśmiertelność. Autor pokazał się w nim jako poeta refleksyjny, skupiony na historii, losach znakomitych postaci z dziejów Polski, twórcach jej dawnej świetności, głównie z czasów romantycznych ${ }^{3}$. Tego typu odwołania miały pokazać ponadczasowe problemy społeczności, natomiast powoływanie się na romantyczne pierwowzory wynikało z przekonania Lechonia o prymacie literatury tamtych czasów i z romantycznej koncepcji poezji, która podnosi ducha narodu oraz łączy tradycje z nowoczesnościa.

Omawiając tom, Roman Loth zauważa, że w utworach z Karmazynowego poematu obecne są elementy epickie: fabuła, narrator, obiektywizacja świata przedstawionego, realia historyczne. Opis sytuacji i prowadzenie watku fabularnego bywa uteatralizowane - dzięki znakomitej reżyserii i świetnej plastyce scen zbiorowych, a także udramatyzowaniu struktury wydarzeń przestawianych z rosnącym napięciem i rozładowanych jak w dramacie - nieoczekiwanym finałem ${ }^{4}$.

3 W swoich wierszach Lechoń nawiązywał m.in. do: Juliusza Słowackiego Grobu Agamemnona, Anhellego, Balladyny, Benionskiego, Fantazego, Snu srebrnego Salomei; Adama Mickiewicza Pana Tadeusza i Dřadów; Zygmunta Krasińskiego Irydiona i Nie-Boskiej komedii, a także do takich twórców, jak: Johann Wolfgang Goethe, George Byron, William Shakespeare, Cyprian Kamil Norwid, wspominał Jana Kilińskiego, Józefa Poniatowskiego, Józefa Piłsudskiego (którego darzył niezwykłą estyma), Dantego, Marcela Prousta, Stefana Starzyńskiego, Tadeusza Kościuszkę, Jana Matejkę, Jana Kazimierza, Józefa Chełmońskiego, Platona, Sokratesa.

4 R. Loth, Wstẹp, [w:] J. Lechoń, Poezje, wstęp i oprac. R. Loth, Warszawa 1990, s. XLVI. 
Po przeczytaniu recenzji Karmazynowego poematu, wypowiedzi krytyków, poetów i ludzi kultury, w których towarzystwie Lechoń od dawna się obracał, nie można mieć wątpliwości, że zbiór ten został uznany za literackie objawienie. Juliusz Sakowski wspominał, że debiut poetycki Lechonia przyjęto na kolanach, mimo że nie zawierał w sobie nic z krzyku pokolenia. Widać w nim było jednak rękę mistrza ${ }^{5}$. Kazimierz Wierzyński z kolei pamiętał oszołomienie, które odczuwano, czytając debiutancki tom, napisany ręka geniusza wtedy, gdy największym utrapieniem pisarstwa bywają jeszcze błędy ortograficzne ${ }^{6}$. Wierzyński wskazał na napięcie uczuciowe tego zbiorku, treść ideową, którą wnosił, oraz fugę poetycka. Swoje rozważania podsumował następująco: „Stoimy przed pięknem bez skazy, które nie potrzebuje żadnych dopełnień"7. Wiktor Weintraub natomiast uznał, że Lechoń od razu wybuchnął jako olśniewający, wielki, dojrzały talent. Przebojem zdobył sobie pozycję wielkiego poety ${ }^{8}$.

Podobne wypowiedzi można by mnożyć. Sakowski zaakcentował także - co jest kluczowe dla rozważań nad pisarstwem Lechonia - iż pasowano go na następcę wielkich romantyków i wiele się po nim spodziewano. Nazywał go Słowackim, który chciałby być Mickiewiczem?. Wydawać by się mogło, że status czwartego wieszcza, który osiągnął spektakularnym debiutem, dogadzał nie tylko ambicjom jego matki, lecz także jego własnym. Z zapisów dokonanych przez Lechonia w Drienniku trzydzieści lat później wiemy, w jak ciężkim stanie emocjonalnym był wówczas: „[...] nie było wtedy mnie - tylko rozdygotane medium piszące pod dyktando tajemnych, gnębiących potęg"10.

Młody poeta pisał w stanie maksymalnego napięcia nerwowego, ze świadomością, że stara się o poetycki wawrzyn. Napięcie było tak duże, że w 1921 roku usiłował targnąć się na swoje życie, przedawkowując weronal. W stanie ogromnej odpowiedzialności za słowo, usiłując utrzymać status poetyckiego objawienia, napisał w 1924 roku Srebrne i czarne. Tom

5 J. Sakowski, Żałobny pas lity, [w:] Pamieci Lechonia, Londyn 1958, s. 3.

6 K. Wierzyński, O poezji Lechonia, [w:] Pamieci Lechonia, s. 55.

7 Ibidem, s. 58.

8 W. Weintraub, Karmazynowe i crarne, [w:] Pamieci Lechonia, s. 74.

9 J. Sakowski, Żałobny pas lity, s. 4.

10 J. Lechoń, Dziennike, t. I, s. 289. Zapis z 8 VIII 1951 r. 
przyjęty został z aplauzem i ukazywał człowieka podlegającego zrządzeniom Fortuny, tragicznego, uwikłanego w ograniczenia własnej natury. Miłość, śmierć, niespełnienie, ukazane w oprawie barokowo-romantycznej, należą do głównych wątków tematycznych zbioru mieszczącego dwadzieścia wierszy. Mówi on o rzeczach ostatecznych i utrzymany jest w tonie duchowej samotności pierwszoosobowo wypowiadającego się podmiotu mówiącego. Srebrne i czarne zostało uznane przez Czesława Zgorzelskiego za jedna z najbardziej konsekwentnych i najefektowniejszych manifestacji pesymizmu w poezji polskiej ${ }^{11}$.

Srebrne $i$ czarne nie jest już, jak Karmazynowy poemat, wypowiedzią zbiorowa, emanacją polskości, lecz wyznaniem jednostki, liryka głęboko osobista, wypełnioną barokowymi antytezami, oksymoronami, hiperbolami i inwersjami. Podmiot liryczny, choć usytuowany w stylistyce baroku, duchowo jest romantykiem podlegającym ekstremalnym doznaniom duszy. Wiersze $z$ tego tomu zbudowane są według przemyślanej klasycznej konstrukcji, a zakończone zmyślnymi pointami.

Lechonia charakteryzowały jego postawy patriotyczne. W 1927 roku znalazł się w delegacji przewożącej zwłoki Słowackiego do Polski. Swoje zadanie wypełnił z niezwykłą powagą i godnością, którą zadziwił rówieśników. Gesty Lechonia obrazowały jego stosunek do romantycznego poety, ale również pokazywały wymiar osobistego patriotyzmu:

Stanąłem na przystani wraz z delegacją pisarzy, oczekując, aż posuwający się wolno statek żałobny przybije do brzegu. Wszakże ani widok statku, ani tłum milczący na brzegu, nie poruszył mnie tak bardzo jak postać Lechonia, który stał przy trumnie, pełniąc straż honorową. Musiał trwać długo na swoim posterunku, gdyż twarz miał osmoloną dymem z jarzących się na statku pochodni. Dzień nie był ciepły. Lechoń, mając na sobie tylko frak, stał z odsłoniętą głową. Zdumiał nas. Odziani w palta, gotowi do uchylenia kapeluszy na krótką chwilę, widzieliśmy w jego postawie patetyczny gest, który jednych wzruszał, innych gniewał, głupców śmieszyl ${ }^{12}$.

Lechoń utrzymywał, że „wychowywanie na Słowackiego” zniszczyło mu życie, zmuszało do wyczynów poetyckich niemal nieosiągalnych:

11 Cz. Zgorzelski, ,Srebrne i czarne” Lechonia, „Pamiętnik Literacki” 1967, z. 1, s. 120.

12 F. Goetel, Lechoń, [w:] Wspomnienia o Janie Lechoniu, oprac. P. Kądziela, Warszawa 2006, s. 92. 
[...] Dla innych - jestem po Karmazynowym poemacie i Srebrne i czarne obowiazany pisać jeszcze lepiej. Bardzo przepraszam, ale to jest niemożliwe. Moge tylko napisać coś większego rozmiarem - dramat poetycki lub poemat. Ale jako materia poetycka - nic lepszego dać nie mogę, niż dałem ${ }^{13}$.

Mimo tych dramatycznych wyznań, konsekwentnie przez całe życie kształtował Lechoń swoją pisarską biografię na wzór romantycznego wieszcza, czyniąc go świątynią twórczości własnej, a także wszelkich pisarskich odniesień.

Sakowski zauważył, iż Lechoń

Nie miał nabożeństwa dla żadnej ze współczesnych wielkości poetyckich Francji i Anglii, nudzili go zarówno Eliot jak Éluard, niecierpliwili misjonarze o wattpliwej misji, magowie bez magii. Na pewno nad Eliota przedkładał starego Kniaźnina, nad Éluarda - poczciwie rzewnego Karpińskiego ${ }^{14}$.

Z notatek diariuszowych wyłania się obraz aktywnego czytelnika ceniącego Alberta Camusa, Marcela Prousta, Juliana Tuwima i wielu innych, zainteresowanego polskim malarstwem - Aleksandra i Maksymiliana Gierymskich, Jacka Malczewskiego, Witolda Wojtkiewicza, zasłuchanego w muzykę Stanisława Moniuszki i Artura Rubinsteina. Jednak to tradycja romantyczna, pomieszczona w klasycznych wierszach, wypełniła twórczość Lechonia. We wstępie do Poezji wybranych Mickiewicza, wydanych w 1946 roku w Londynie, porównywał go do Homera, Dantego, Shakespeare'a i Johanna Wolfganga Goethego. Trzeba to podkreślić - Mickiewicz był dla Lechonia literacka jednostką miary.

Lechoń zaszczepił w swoich wierszach motywy romantyczne, dokonywał transplantacji motywów malarskich i muzycznych na poezję. Posługiwał się nieustannie językiem mitów i tradycji literatury. Za Mickiewiczem uznawal, że warunkiem osobistego i narodowego rozwoju jest związek z przeszłością. Pomieszczane w kolejnych tomach jego wiersze o Polsce, polskości i dramatach narodu były kontynuacją wielkiej tradycji romantycznej. Pozostało tak do końca życia Lechonia, który pisał jak romantyk i klasycysta nawet wówczas, gdy w powojennej ojczyźnie koledzy

13 J. Lechoń, Driennik, t. I, s. 401 . Zapis z 9 IX 1950 r.

14 J. Sakowski, Żałobny pas lity, s. 7. 
posługiwali się już językiem socrealizmu. Wiersze Lechonia uznać możemy za lirykę osobistą i uniwersalną zarazem.

Lechoń był całkowicie nieprzystosowany do zajęć dnia codziennego. Uważał, że zabijają one natchnienie twórcze. Boleśnie odczuwał swoje zajęcia zarobkowe. Przez pryzmat ten postrzegał także Mickiewicza. Pisarz ten był dla niego osobą wyabstrahowaną z rzeczywistości. Za jego niemoce winił żonę i obowiązki ojca rodziny ${ }^{15}$.

Wiktor Weintraub zapamiętał ostry spór z Lechoniem, wzburzonym bardzo po ukazaniu się książki Weintrauba o Mickiewiczu ${ }^{16}$. W publikacji tej Weintraub uznał nagłe zamilknięcie Mickiewicza po 1843 roku za katastrofę. Lechoń ripostował, że nie można mówić o katastrofie w przypadku pisarza, który miał na swoim koncie takie arcydzieła, jak Pan Tadeusz. i Driadów część trzecia. Spór z Weintraubem długo zajmował uwage poety. Komentował go kilkakrotnie na przestrzeni roku, m.in. w Driennike $u^{17}$ oraz w liście do Mieczysława Grydzewskiego ${ }^{18}$. Zamilknięcie twórcze Mickiewicza i własne było wielkim kompleksem Lechonia. Tłumacząc wieszcza, usprawiedliwiał również długie miesiące, a nawet lata swojej poetyckiej niemocy, rozpoczęte w drugiej połowie lat 20., kontynuowane w okresie pobytu w Paryżu przez całą trzecią dekadę, a zarzucone dopiero podczas nowojorskiej emigracji.

Lechoń traktował Mickiewicza jako alter ego, więc w obronie wieszcza chodziło w rzeczy samej o autoterapię:

[...] Twórczość poetycka Mickiewicza, która przeżył o lat dwadzieścia, nie mogła po napisaniu Drziadów i Pana Tadeusz̧a wznieść się wyżej, że nie tylko w dwóch jakże odmiennych rodzajach osiagnął on szczyty poetyckiego wyrazu - ale zarazem stworzył w Dziadach mit narodowy, zdolny do ciągłego życia i odradzania się w duszy polskiej, a w Panu Tadeuszu dał poetycki wyraz ziemi polskiej i polskiego narodu. Po takich dokonaniach miał prawo uważać swoje zadanie za skończone i sądzić jak najsurowiej swoje późniejsze wiersze, choć mogły być one chlubą innych poetów ${ }^{19}$.

15 J. Lechoń, Dziennike, t. III, s. 663. Zapis z 18 VII 1955 r.

16 W. Weintraub, Poeta i prorok. Rzecz o profetyzmie Mickiewicza, Warszawa 1982 (pierwsze polskie wydanie).

17 J. Lechoń, Driennik, t. III, s. 539. Zapis z 7 I 1955 r.

18 M. Grydzewski, J. Lechoń, Listy, wstęp i oprac. B. Dorosz, Warszawa 2006, s. 426-427. List z 22 III 1956.

19 J. Lechoń, O literaturže polskiej, Warszawa 1993, s. 143. 
Odnosząc sytuację Mickiewicza do własnej, wracał Lechoń do sporu z Weintraubem, wciąż bardzo wzburzony:

I co to w ogóle za bezczelne wymagania od poety, żeby ciagle pisał. Od poety, który już napisał Sonety krymskie, Pana Tadeusza i Driady. On chciałby, żeby Mickiewicz ciagle pisał i „podciagał się", i ciagle czekał, aż mu jakiś Weitraub czy, broń Boże, Backvis postawi stopień. A oni by się ociagali i ciagle zadawali mu poprawki, bo co to ich kosztuje ${ }^{20}$.

Pochlebne noty o wieszczu wywoływały w Lechoniu natomiast wielką aprobatę, do tego stopnia, iż wypowiedzi te plasował między najlepszym, co napisano w ogóle o literaturze. Warto zauważyć rys psychiczny Lechonia tęskniącego do romantycznych dworków, zakleszczonego mentalnie i emocjonalnie w konserwie historii:

Artykuł Przybosia o Mickiewiczu jeszcze bardziej mi się dziś podobał, niż przy pierwszym czytaniu, sa to jedne z najpiękniejszych stronic, jakie napisano u nas nie tylko o Mickiewiczu, ale o poezji w ogóle. Powróciwszy do tej lektury, pomyślałem sobie: wszyscy Polacy czują tak samo, może ci w niewoli bardziej czuja pewne rzeczy niż my. Cytaty, które Przyboś wybrał, mogłyby nawet oznaczać nie tylko uwielbienie dla poezji Pana Tadeusza, ale niemal tęsknotę do świata Pana Tadeusza $a^{21}$.

Wzruszony artykułem Juliana Przybosia, Lechoń zauważył, iż wyszedł on spod pióra pisarza, który życie poświęcił, czy raczej zmarnował, aby pisać inaczej niż Mickiewicz.

Szok spowodowany wybuchem II wojny światowej zmotywował Lechonia do chwycenia za pióro i wydania trzech tomów poetyckich (Lutnia na Bekwarku, Londyn 1942; Aria z kurantem, Nowy Jork 1945; Poezje zebrane 1916-1953, Londyn 1954). Zbiory te ukazuja poczucie jedności ze wspólnotą narodową. Lechoń po raz kolejny tworzy w oparciu o związki z tradycja, porównując współczesne mu losy narodu do jego dziejów z czasów rozbiorów Polski oraz do epoki romantyzmu. Poeta odnosi się również do rodzimej, tradycyjnej religijności. Podmiot liryczny wierszy z okresu nowojorskiego idealizuje ojczyste klimaty: przyrodę, kulturę, tradycję, wokół nich skupiając emocjonalny wywód. W tamtym czasie powstaje też obszerny dziennik pisany przez Lechonia regularnie w latach 1949-1956, w którym mnożą się

20 J. Lechoń, Džiennike, t. III, s. 807. Zapis z 17 III 1956 r.

21 Ibidem, s. 640. Zapis z 11 IV 1955 r. 
zapiski zdradzające, iż swe powstające wówczas utwory uznawał za dorobek zbyt skromny jak na swoje ambicje. Dochodziły do tego skomplikowane stany psychiczne, przypominające emocjonalne młodzieńcze burze. Systematyczna praca i modlitwa, sygnalizowana powtarzanym po wielokroć zawołaniem ora et labora, miała być dla Lechonia ratunkiem:

Dwie stronice gorzej niż wczoraj. I z wielkim trudem. Cudze zmartwienia znów mnie zasnuły jak gradowa chmura. Od dawna nie miałem tak złego dnia. Może były i powody - ale najważniejszy był we mnie. Czułem się przeklęty, jakbym sam się chciał popychać na dno 22 .

I w innym miejscu:

Obrzydliwe uczucie, że nigdy nie pisałem, zdziwienie, że można pisać, można robić coś tak dziwnego. Pocieszam się, że to zmęczone nędzne ciało i że pod nim drzemie druga dusza, gotowa znów się obudzić, albo mówiąc prościej, drzemie zmęczony pisarz ${ }^{23}$.

Wiadomo jednak, że Lechoń sam bardzo chciał się podciągnąć, by zasłużyć na dobry nekrolog i pochówek w krypcie zasłużonych na Skałce ${ }^{24}$. W tamtym czasie zaczął porównywać swoją biografię do życiorysów wybitnych ludzi, bacznie śledząc ich dorobek ${ }^{25}$ lub też obliczając wiek debiutu: „Dziś skończyłem 52 lata, czyli mam tyle, ile Mickiewicz po napisaniu wszystkiego, gdy był już u schyłku życia" ${ }^{26}$. Takie porównania skutkowały podwyższeniem własnej poprzeczki. Lechoń pragnął być zapamiętany jako ostatni z wieszczów, miał jednak świadomość, że wieloletnie niemoce twórcze moga zniweczyć tę ambicję. Skłonność do porównań pozostała mu do końca życia. Wielokrotnie dywagował:

Czy Mickiewicz, który napisał Pana Tadeusza mając lat 36, Słowacki, Chopin, Wyspiański, Malczewski, Mochnacki, którzy dokonali swego dzieła przed 40-ką, rozwijali się wcześniej niż my? Taki jest pozór, ale prawda

22 Ibidem, s. 39-40. Zapis z 12 II 1953 r.

23 Ibidem, s. 615. Zapis z 3 V 1955 r.

24 Zob. M. Urbańska, „Dobry nekrolog” Jana Lechonia, [w:] Pamię́c, red. M. Urbańska, Lódź 2016, s. 35-44.

25 „Michał Anioł miał 37 lat, gdy namalował plafon sykstyński. Nie mam się za Michała Anioła - ale trzeba sobie raz po raz powtarzać: «A ty?»”, J. Lechoń, Dziennike, t. I, s. 351. Zapis z 18 VII $1950 \mathrm{r}$.

26 Ibidem, t. II, s. 71. Zapis z 13 III 1951 r. 
tkwi w tym, że byli oni geniuszami, czy wielkimi talentami - podczas gdy w naszym pokoleniu wyrosłym w zszarzałym świecie nie ma geniuszów ${ }^{27}$.

Często zastanawiał się, czy to wypada Słowackiemu i czy Słowacki mógłby tak postapić, myśląc o własnym rozdwojeniu na starego mistrza i ciągłego młodzieńca. Zauważył jednocześnie takie samo rozdwojenie u Goethego i z ulgą skonstatował, że wobec tego nie ma się czym aż tak martwić ${ }^{28}$. Uważał, że klasyczna literatura polska była tą, w której polski duch wypowiedział się całkowicie i najwspanialej ${ }^{29}$, jednocześnie zdając sobie sprawę, że następuje wymiana pokoleń i gustów literackich. Nie był to jednak dla niego wystarczający imperatyw, by swoją twórczość przewartościować. Lechoń już w latach 20. XX wieku wzbudzał zdziwienie niemodnym wyglądem, gdy we fraku i kapeluszu przechadzał się po Starym Mieście w Warszawie. Tak samo nosił się także w latach 30. w Paryżu oraz w 40. i 50. w Nowym Jorku. Zewnętrzność poety odzwierciedlała jego klasyczne upodobania literackie. Z rozmysłem kreował się na romantycznego wieszcza. Dystans człowieka dojrzałego, wtajemniczonego w to, co zbiorowości ludzkiej niedostępne, zachowującego klasyczny dystans artysty do tragicznych zdarzeń widać również w poezji Lechonia:

My z starym Sofoklesem spokojnie patrzymy

$\mathrm{Na}$ ten widok, na który chciałbyś zamknąć oczy ${ }^{30}$.

Mówią mi: „Nic nie wskrzesi czasu co przeżyty,

Wkrótce i o nim pamięć wśród młodych się zatrze.

Zabieraj ze sobą swoje stare rekwizyty,

Bo nową będą grali sztukę w teatrze ${ }^{31}$.

Lechoń utrzymywał, że w literaturze romantycznej, poprzez symbole właściwe dla marzycielskiej natury naszego narodu, wyrażała się rzeczywistość oraz życie duchowe. Poezje Lechonia charakteryzował patos, strategia literacka, którą stosował świadomie przez cały okres swej

27 Ibidem, s. 335. Zapis z 7 I $1951 \mathrm{r}$.

28 M. Urbańska, „Dobry nekrolog”..., s. 35-37.

29 J. Lechoń, O literaturze polskiej, s. 13.

30 J. Lechoń, [*** Od żalu nie uciekniesz, nie ujdziesz goryczy...], [w:] idem, Poezje, s. 63.

31 J. Lechoń, Poeta niemodny, [w:] idem, Poezje, s. 198. 
twórczości: „Pomyślałem sobie, że przecież coś się musi dziać z moim patosem, bez którego nie byłoby moich wierszy - bez którego nie byłbym sobą"32.

Istotnie, patos stanowił ważny element wizerunku, który Lechoń obrał za własny, ignorując to, co codzienne, na rzecz niezwykłego, wywodzącego się ze sfery sacrum, z salonów i teatralnej sceny. Umiłowanie do tego, co już przebrzmiałe, usprawiedliwiał Mickiewiczem:

Mickiewicz pokazuje nam ich [nowości, tradycji i współczesności] względność i wieloznaczność, pokazuje nam, jak później Wyspiański, że nowość $i$ tradycja nie są ze sobą sprzeczne, ale że przeciwnie, największe przewroty literackie czynili ci właśnie, którzy wchłonąwszy w siebie przeszłość, znaleźli przez to instynktowną miarę nowości ${ }^{33}$.

Warto zauważyć, że w poezji Lechonia, mimo wielogłosowości i dialogizacji wypowiedzi, mamy do czynienia ze spojrzeniem z tej samej, homofonicznej perspektywy literackiej ${ }^{34}$.

Świadom anachroniczności swego dzieła bardzo niechętnie wypowiadał się Lechoń o poetach młodszych, którzy w okresie powojennym zaczęli wyznaczać w polskiej literaturze nowe tendencje literackie. Niesprawiedliwych recenzji doświadczyli z jego strony szczególnie Witold Gombrowicz i Czesław Miłosz. Z wywodów Lechonia na temat tego drugiego, notowanych w dzienniku, wynika jasno, że jego niechęć dotyczy nie tylko twórczości Miłosza, lecz ma także podłoże w rywalizacji „Wiadomości” z „Kulturą” i w pogardzie Lechonia dla poetów, którzy układali swe literackie losy w kraju:

Rozmowa o Miłoszu, która doprowadziła mnie do dzikiej furii, tak że jeszcze teraz cały kipię. Cała ta sprawa to dowód zupełnej aberracji „Kultury”

32 J. Lechoń, Driennik, t. III, s. 359. Zapis z 1 V 1954 r. R. Loth zaznacza, że „Karmazynowy poemat - to również patos. Patos nie tylko tematu, ale też obrazowania, frazeologii, słownictwa. Lechoń starannie dobiera motywy i symbole monumentalizujące tekst, operuje wzniosłym epitetem i hiperbolą. Ma w tym swój udział często pojawiająca się aluzja do uznanych w tradycji kulturowej wielkich dzieł literatury, malarstwa i teatru. Ta wzniosłość zbliża wiersze do stylu retorycznego poezji. Z tegoż stylu wywodzi się widoczna troska poety o kunsztowność środków wyrazu, jemu też przypisać można obecność takich konstrukcji i form, jak apostrofa (i towarzyszący jej tryb rozkazujący czasownika), powtórzenie, wyliczenie”. Zob. R. Loth, Wstęp, s. XLVII.

33 J. Lechoń, O literaturze polskiej, s. 13.

34 Zob. B. Czarnecka, Ruchomy na szali wagi. Lechoń homotekstualny, Toruń 2013. 
i tych wszystkich, którzy pokornie czytają to pismo. Miłosz brał reżymowe pieniądze wtedy, kiedy rozstrzeliwano najlepszych Polaków, i jeszcze teraz uraga i daje moralne nauki emigracji. Rajchman, Matuszewski umarli skrzywdzeni, jeden na progu biedy, a drugi po latach całych konania w nędzy. I „Kultura”, i jej redaktorzy-moraliści nawet tego nie dostrzegli, nawet nie dostrzegli, że Rajchman umart ${ }^{35}$.

W innym miejscu zanotował: „Czytam teraz trzy zimy Miłosza, które kiedyś wydawały mi się dobre. «Gówno», jak powiedział Or-Ot w czasie ekshumacji Słowackiego"36.

W podobnym tonie, zdegustowanego krytyka literackiego, klasyfikującego pisarzy według swojej miary, wypowiadał się Lechoń o Gombrowiczu. Zanim przytoczę ów osąd pragnę zaznaczyć, że subiektywne, emocjonalne wypowiedzi oraz krańcowe osądy były dla Lechonia charakterystyczne. Wyrażając swą opinię o pisarzach, jednych sytuował na piedestale, innych deprecjonował. Gdy argumenty do obrony własnej tezy były zbyt małej wagi, powoływał się na swój wiek, wiedzę i znajomości:

Artykuł Gombrowicza o poezji czytam na wyrywki, z obawy, że cała porcja wywróciłaby mi wątrobę do góry nogami. Parę zdań wczoraj przeczytanych też mi groziły jakimś atakiem żółci, cóż za bezczelność, cóż za efronteria! $\mathrm{Na}$ świecie najwięksi pisarze, najtęższe umysły tomy pisali na temat między poezją a literaturą - wielcy poeci umierali w nędzy, aby produkować w boleściach tę esencję nie mającą nic wspólnego z tym ,wypowiedzeniem się", o którym baje Gombrowicz. I oto przychodzi facet, którego właściwie $3 / 4$ inteligentnych Polaków nie chce i nie umie czytać, i twierdzi, że wszystko jest humbug, zmowa jakichś snobów i kombinatorów. I pismo zwane „Kulturą” drukuje to objawienie na pierwszym miejscu. Dosyć! Bo czuję, jak mnie kraja w dołku ${ }^{37}$.

Po pewnym czasie, pytany o Lechonia, Gombrowicz zabierał głos i konstatował, wskazując na anachroniczność autora Karmazynowego poematu, który skończył się w momencie, gdy nie miał już nic do powiedzenia, teatralnie recytując już tylko stare, osłuchane frazy:

Tragikomiczna sytuacja, gdy wszystkie te Lechonie zostały przyparte do muru: teraz musisz coś wydusić z siebie, skok, inspirację, ideę, coś

35 J. Lechoń, Driennik, t. II, s. 209. Zapis z 15 IX 1953 r.

36 M. Grydzewski, J. Lechoń, Listy, t. I, s. 118.

37 J. Lechoń, Driennik, t. II, s. 297. Zapis z 23 XI 1951 r. 
niespodziewanego i niebywałego, żeby wytrącić Historii inicjatywę! Odpowiedzieli recytując wszystkie dotychczasowe utwory plus nowe, akurat takie same, kubek w kubek. Wszystko pięknym językiem, wzorową składnią, kulturalnie, z godnością i przecinkami ${ }^{38}$.

Gombrowicz się nie mylił. Właśnie z takim problemem - pisania bardzo do siebie podobnych wierszy retorycznych, rekrutujących się z jednego klasycznego lub romantycznego źródła - Lechoń się borykał:

Ciagle mi chodzi po głowie jakiś wiersz dla Kraju - przecież coś można, coś powinno się napisać z tego, czego oni pisać nie mogą. Dzisiaj myślałem, aby to był znowu Gustaw Konrad, który przecież powinien zmartwychwstać w tym właśnie roku. Ale bardzo mi teraz nie do patosu. A raczej wiem, że ten patos powinien być hamowany, bez retoryki. Koniecznie wziąć się do tego i próbować, póki mi nie wyjdzie ${ }^{39}$.

Gombrowicz, nazywany przez Lechonia durniem, bęcwałem, wiecznym gówniarzem, którego nie należy dopuszczać do poważnej rozmowy, podjął z nim stanowczy i rzeczowy, nie zaś oparty na emocjach dialog, wskazując na:

Chaos. Ciemność. Pasje i podrażnienia wręcz naskórkowe. Lata spędzone w Paryżu spłynęły po nim jak deszcz po dachu. A gdy Historia wyrzuciła do na dobre z Polski, utopił się w szerokim świecie akurat tak samo, jak pierwszy lepszy dziedzic wygnany $z$ folwarku ${ }^{40}$.

Problem Lechonia polegał na tym, iż pretendował do roli wieszcza, pragnął wyznaczać literaturze kierunek, a u schyłku życia uświadamiał sobie, że staje wobec coraz większej czytelniczej obojętności, którą przełamała dopiero sensacyjna wiadomość o jego samowolnej śmierci. Deprecjonowani przez niego Gombrowicz i Miłosz zrzucili go z literackiego piedestału, czyniąc to $\mathrm{w}$ powolnym procesie nie tylko wymiany pokoleń, ale też naturalnej ewolucji literackich gustów. Usilne i naiwne próby przeniesienia struktur przedwojennej Warszawy do Nowego Jorku wyznaczały wyraźnie rys osobowości Lechonia. Kulturę rozumiał jako pole działania pewnej elitarnej społeczności. Działanie to odbywało się

38 W. Gombrowicz, Driennik 1957-1961, Paryż 1971, s. 176.

39 J. Lechoń, Driennike, t. III, s. 748. Zapis z 16 XII 1955 r.

40 W. Gombrowicz, Dzieła zebrane, t. X, Paryż 1973, s. 509. 
według wyznaczonych ról i ceremonii. Sakralizacja i ceremonializacja działań miała dla poety znaczenie kluczowe. Wobec tradycji cechował go stosunek wyznawczy. Stosunki międzyludzkie w ramach społeczności regulowała pozycja jednostki w tej hierarchii. Spory, także literackie, załatwiał deprecjonując interlokutora, na przykład poprzez zaakcentowanie jego młodego wieku („szczeniak”), mniejszego doświadczenia lub mniej spektakularnych niż Lechonia kontaktów i znajomości. Jako że po wojnie działał w „Warszawie zrekonstruowanej” w oparciu o stare układy i zależności, jego współpracownikami rzadko byli reprezentanci młodszego pokolenia. Jego zakotwiczenie w anachroniczności widać, gdy przypomnimy sobie, że ulubioną małą formą literacką Lechonia był nekrolog i wspomnienie pośmiertne. Natomiast tradycja, na którą Lechoń się powoływał, była z jednej strony dobrze utrwalona w czytelniczej świadomości, z drugiej zaś stawała się anachroniczna, ustępując miejsca nowym formom utożsamienia kulturowego.

Lechoń nie znosił, gdy młodsi pisarze nie reprezentowali wyznawczego stosunku do literatury dawnej, gdy eksperymentowali z poetycka forma oraz skupiali swoją myśl na aktualnych problemach, których on nie czuł, nie rozumiał i nie doceniał. To w osobie Mickiewicza widział zagadkę tradycji i nowości:

Gdyby ataki na mnie i na moje pokolenie poetyckie były podjęte przez jakichś naprawdę nowatorskich, jak nowatorskim był w swoim czasie Tuwim - byłoby to bardzo przykre, ale zarazem zrozumiałe. Ale że wycierają sobie nami gębę zasrańcy bez talentu, smarujący jeden wiersz bez sensu i rym po parę lat, albo skomplikowane eunuchy - to doprawdy warte śmiechów. Myśmy byli prawdziwymi zwycięzcami w Pro Arte i Skamandrze, i mimo to ceniliśmy wszystko, co było dobre w przeszłości. Złościłem się tymi napaściami przez kilka dni, ale już mi zupełnie przeszło. Niech sobie pisza, ile chca, nawet niech ich czytają i chwalą tacy sami starzy gówniarze jak oni i ogłupiona przez nich młodzież $\dot{z}^{41}$.

Warto dodać, iż wspomnianego Skamandra wywodził Lechoń od Mickiewicza, argumentując tę opinię następująco:

Bo Mickiewicz był romantykiem i klasykiem. Tuwim, ja i Słonimski mieliśmy się doskonale w tym dziedzictwie, dziedzictwie zarazem Džiadów,

41 J. Lechoń, Dq̃iennik, t. III, s. 221. Zapis z 3 X 1953 r. 
Sonetów krymskich, połączeni tym, od czego nigdy Mickiewicz nie odstapił - precyzja, ścisłą formą, na którą właśnie gwizdała Młoda Polska, drugi szereg Młodej Polski ${ }^{42}$.

Przynależność do Mickiewicza pomagała Lechoniowi znosić niedogodności uchodźstwa. W połowie lat 50., czytając opis pogrzebu wieszcza, dochodził do wniosku, że Polacy rzuceni za ocean, nie wyrzekając się nadziei, coraz bardziej jednak stają się emigracją, a „Mickiewicz to nie tylko największy poeta całego naszego narodu - to też nasz, wygnańców, starszy brat, nasz nieszczęsny ojciec w wygnaniu i tęsknocie" ${ }^{\text {43 }}$.

Faktycznie, dziesięć lat po zakończeniu wojny Lechoń coraz częściej brał pod uwagę, że do ojczyzny już nie wróci. Był to jego sprzeciw wobec komunistycznej dyktatury: „O śmierci się wie, ale się w nią nie wierzy. I tak samo wiemy, że może nie wrócimy do Kraju, ale nie można w to wierzyć, nie można żyć z tą wiara - choć tylu nie wróciło i nawet po śmierci nie wróci" ${ }^{44}$.

Rok przed śmiercią poeta zaczął pracę nad jubileuszem stulecia śmierci Mickiewicza, którego w cyklu wykładów O literaturze polskiej wygłoszonym w Paryżu sytuował w centrum literackich i dziejowych wydarzeń:

Mickiewicz stoi właśnie pośrodku zagadnień, które będą nas tu szczególnie zajmowały, w nim właśnie zawarte jest zgodnie z niedościgłą harmonia piękno wszystkiego, co było zawsze w duszy polskiej, co było dziedzictwem historii i dawnej poezji, z największym porywem do nowości, do przemiany; w jego poezji, w jego dziele politycznym, w jego życiu nawet zamyka się zagadka tradycji i nowości ${ }^{45}$.

Przygotowania audycji radiowych, odczytów oraz książki kosztowały Lechonia dużo pracy, której wartości nie był pewien. Korespondując z Grydzewskim, zwierzał się, iż Mickiewicz przywalił go jak trumna św. Stanisława i prosił, aby przyjaciel westchnął za nim, aby się z tego podźwigną ${ }^{46}$. Kończąc pisanie, podsumował: „Dokończyłem Mickiewicza, płacząc ze wzruszenia, co wcale nie oznacza, że napisałem coś z sen-

42 Ibidem, s. 505. Zapis z 19 XI $1955 \mathrm{r}$.

43 Ibidem, s. 613. Zapis z 30 IV 1955 r.

44 Ibidem, s. 615. Zapis z 3 V 1955 r.

45 J. Lechoń, O literaturze polskiej, s. 11.

46 M. Grydzewski, J. Lechoń, Listy, t. II, s. 390. List z 20 VIII 1955 r. 
sem" ${ }^{47}$. Nowojorskie obchody śmierci wieszcza miały miejsce w Polskim Instytucie Naukowym $26 \mathrm{~V} 1955$ roku.

Lechoń miał do Mickiewicza stosunek wyznawczy. Cykl poświęcony literaturze polskiej jest tak naprawdę pomnikiem wystawionym polskiemu wieszczowi, który jawi się jako punkt odniesienia wszystkich poruszanych przez Lechonia zagadnień. Mówiąc o literackim dziedzictwie rodzimym, cały czas odnosił się on do emocji i subiektywnych odczuć, na których budował sądy ogólne, uznając je za obowiązujące. Sprzeciwu nie tolerował, co obrazuje wspomniany już spór z Weintraubem.

Lechoń był świadom tego wszystkiego, co obrazują następujące wyznania:

Prześladuje mnie myśl zarazem megalomańska i pełna pokory, że mogłem być tak wielkim poeta - jak... nie powiem kto, ale na to powinienem był inaczej zupełnie urządzić się w życiu, nie zawracać sobie głowy jakimiś ambasadami, „Tygodnikami”, żadną polityką i trzymać na łańcuchu zarówno Wenus, jak i Anakreonta. A poza tym trzeba było nie myśleć ciagle: to już napisano, to już Mickiewicz zrobił lepiej ode mnie - tylko pisać tak, jakby nikt przede mną niczego nie napisał. W rezultacie znaczy to, że trzeba by się było urodzić po raz drugi i nie sobą. Czyli że nie ma co biadać, bo nie mogłem przecież nie być sobą. A swoją drogą - szkoda ${ }^{48}$.

W innym miejscu, komentując prace nad nowym wierszem, zanotował:

Ciągle mi się zdaje, że w tym wierszu powinien być też Mickiewicz, ale to chyba nałóg myślowy, to ciagłe konfrontowanie siebie, Polski, naszego czasu z Mickiewiczem. Nie trzeba wzywać jego myślenia narodowego. Naśladować go - to znaczy nie pisać o nim, tylko czuć tak jak on, „,najwyższy z czujących",49.

Lechoń, nie będąc sobą, był odtwórczy w pisarstwie oraz prywatnej osobowości. Nieustannie porównując do czyjegoś swe życie i dzieło, zdominował się ową kreacją, kostiumem, dezintegrując się wewnętrznie aż do ostatecznego rozpadu: „Modlić się, paść na kolano i modlić się. I, wbijając sobie paznokcie w ręce, pracować nad czymś poważnym, szlachetnym, żebym znów powrócił do siebie i nie było we mnie miejsca na

47 J. Lechoń, Driennik, t. III, s. 625. Zapis z 25 V 1955 r.

48 Ibidem, s. 527. Zapis z 19 XII 1954 r.

49 Ibidem, s. 783. Zapis z 11 II $1956 \mathrm{r}$. 
tego zrozpaczonego szaleńca, który mi żyć nie daje" ${ }^{50}$. I innym razem: „To samo. Z nóg po prostu leciałem ze zmęczenia nędznego słabej duszy. Wiem, że nie można przesadzać z uciekaniem od siebie - ale też nie mógłbym wytrzymać ze sobą" 51 .

Lechoń rozumiał życie jako walkę maski z cieniem. Uważał, że w życiu praca artystyczna liczy się najbardziej. Najważniejsza była dla niego nieśmiertelność - stąd jego marzenia o pochówku na Skałce. Mistrzowsko opanował rolę Konrada, na niego kreując się twórczo i prywatnie. Zachowanie twarzy Konrada w nienagannej formie - do końca - uznał za najważniejszą ze swych powinności, nieustannie zadając sobie pytanie, co wypada, a czego mu (Lechoniowi-Konradowi) nie wypada. Roli tej pozostał wierny nawet wobec totalnej dezintegracji osobowości. Odczuwając ową dezintegrację (ukrywaną symbolicznie pod postacią Erynii), pod koniec życia uporczywie samoutwierdzał się w formie, ulepszał, poprawiał biografię, myślał o nekrologu, coraz głębiej wycofując się w przestrzeń wewnętrzną. Postępującej introwersji towarzyszyła konsekwentna i coraz bardziej uporczywa ekspozycja wykreowanego wizerunku. Tak silne napięcie i zderzenia tak silnych sprzeczności doprowadzały poetę do stopniowej autodestrukcji.

Lechoń swoją w pełni ukształtowaną osobowość literacką objawił w Karmazynowym poemacie, natomiast kolejne trzy i pół dekady pisarstwa upłynęły mu głównie na staraniach utrzymania wówczas obranych ról i form. Polonijne środowisko Nowego Jorku próbował przekształcić w atrapę przedwojennej Warszawy, przestrzeń zredukowaną, ze starą obrzędowością i ceremonializacja, tylko w takiej bowiem potrafił się odnaleźć. Wniknięcie w struktury amerykańskie nie interesowało go w ogóle. W okresie powojennym, jako poeta anachroniczny, toczył nierówna i przegraną już walkę z przedstawicielami nowej pisarskiej generacji.

Nie jest prawdopodobnie przypadkiem, iż na okrutną samobójczą śmierć na nowojorskim bruku Lechoń zdecydował się, będąc w tym samym wieku, co Mickiewicz. Wielki romantyk zmarł miesiąc przed 57. urodzinami, Lechón popełnił samobójstwo trzy miesiące po swoich 57. urodzinach, kilka miesięcy po setnej rocznicy narodzin umiłowanego poety.

50 Ibidem, s. 604. Zapis z 11 IV $1955 \mathrm{r}$.

51 Ibidem. Zapis z 12 IV 1955 r. 


\section{Bibliografia}

Czarnecka B., Ruchomy na szali wagi. Lechoń homotekstualny, Toruń 2013.

Gombrowicz W., Drieła zebrane, t. X, Paryż 1973, s. 509.

Gombrowicz W., Driennik 1957-1961, Paryż 1971.

Grydzewski M., Lechoń J., Listy, wstęp i oprac. B. Dorosz, t. I-II, Warszawa 2006.

Kosiński J. A., Album rodzinne Jana Lechonia, Warszawa 1993.

Lechoń J., Driennik, oprac. R. Loth, t. I-III, Warszawa 1992.

Lechoń J., O literaturze polskiej, Warszawa 1993.

Lechoń J., Poezje, wstęp i oprac. R. Loth, Warszawa 1990.

Pamieci Lechonia, Londyn 1958.

Urbańska M., „Dobry nekrolog” Jana Lechonia, [w:] Pamię́, red. M. Urbańska, Łódź 2016, s. 35-44.

Weintraub W., Poeta i prorok. Rzecz o profetyzmie Mickiewicza, Warszawa 1982. Wspomnienia o Janie Lechoniu, oprac. P. Kądziela, Warszawa 2006.

Zgorzelski Cz., „Srebrne i cz̧arne” Lechonia, „Pamiętnik Literacki” 1967, z. 1, s. 99-122.

\section{Inspiracje Jana Lechonia}

Jan Lechoń od młodości inspirował się literaturą romantyczną. Jego matka chciała, by - na wzór Juliusza Słowackiego - był kolejnym romantycznym wieszczem. Jej ambicje spełniły się, bowiem Lechoń debiutował jako trzynastolatek, a w 1921 roku, po wydaniu Karmazynowego poematu, uznany został za literackie objawienie.

Do końca życia pozostał wierny klasycznej formie wierszy i romantycznym inspiracjom (zwłaszcza pisarstwu Adama Mickiewicza, które promował), podporządkowując im również prywatne losy. Z biegiem czasu coraz bardziej oddalał się od literatury współczesnej, ignorował twórców nowej generacji, usiłując zachować struktury przedwojennej Warszawy w Nowym Jorku lat 50. XX wieku.

Zmarł śmiercią samobójczą w tym samym wieku, co Mickiewicz, u szczytu swej pisarskiej działalności, jednak w emocjonalnym osamotnieniu i poczuciu wewnętrznego bankructwa. 
From his youth, Jan Lechon was inspired by romantic literature. His mother wanted him to be another romantic bard like Juliusz Słowacki. The mother's ambitions were fulfilled, because Lechoń debuted as 13 years old child, and in 1921, after the release of Karmazynowy poemat, he was considered a literary revelation. Until the end of his life he remained faithful to the classic form of poems and to romantic inspirations (especially to the writings of Adam Mickiewicz, which he promoted), also subordinating them his private fates.

Lechoń was increasingly distancing himself from contemporary literature, ignoring the creators of the new generation, trying to preserve the structure of pre-war Warsaw in New York in the 1950s.

He died a suicide death at the same age as Mickiewicz, at the peak of his writing activity, but in emotional loneliness and a sense of internal bankruptcy. 